\title{
Article \\ Sub-Acute Feeding Study of Saxitoxin to Mice Confirms the Effectiveness of Current Regulatory Limits for Paralytic Shellfish Toxins
}

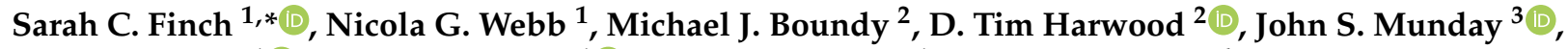 \\ Jan M. Sprosen ${ }^{1} \mathbb{D}$, Vanessa M. Cave ${ }^{1} \mathbb{D}$, Ric B. Broadhurst $^{1}$ and Jeane Nicolas ${ }^{4}$ \\ 1 AgResearch Ltd. Ruakura Research Centre, Private Bag 3123, Hamilton 3240, New Zealand; \\ nikki.webb@agresearch.co.nz (N.G.W.); jan.sprosen@agresearch.co.nz (J.M.S.); \\ vanessa.cave@agresearch.co.nz (V.M.C.); ric.broadhurst@agresearch.co.nz (R.B.B.) \\ 2 Cawthron Institute, Private Bag 2, Nelson 7042, New Zealand; Michael.Boundy@cawthron.org.nz (M.J.B.); \\ Tim.Harwood@cawthron.org.nz (D.T.H.) \\ 3 Department of Pathobiology, School of Veterinary Science, Massey University, Private Bag 11 222, \\ Palmerston North 4442, New Zealand; J.Munday@massey.ac.nz \\ 4 Ministry for Primary Industries-Manatu Ahu Matua, P.O. Box 2526, Wellington 6021, New Zealand; \\ Jeane.Nicolas@mpi.govt.nz \\ * Correspondence: sarah.finch@agresearch.co.nz
}

Citation: Finch, S.C.; Webb, N.G.; Boundy, M.J.; Harwood, D.T.; Munday, J.S.; Sprosen, J.M.; Cave, V.M.; Broadhurst, R.B.; Nicolas, J. Sub-Acute Feeding Study of Saxitoxin to Mice Confirms the Effectiveness of Current Regulatory Limits for Paralytic Shellfish Toxins. Toxins 2021, 13, 627. https://doi.org/10.3390/ toxins13090627

Received: 6 August 2021

Accepted: 5 September 2021

Published: 7 September 2021

Publisher's Note: MDPI stays neutral with regard to jurisdictional claims in published maps and institutional affiliations.

\section{Copyright: (c) 2021 by the authors.} Licensee MDPI, Basel, Switzerland. This article is an open access article distributed under the terms and conditions of the Creative Commons Attribution (CC BY) license (https:/ / creativecommons.org/licenses/by/ $4.0 /)$.

\begin{abstract}
Regulatory limits for shellfish toxins are required to protect human health. Often these limits are set using only acute toxicity data, which is significant, as in some communities, shellfish makes up a large proportion of their daily diet and can be contaminated with paralytic shellfish toxins (PSTs) for several months. In the current study, feeding protocols were developed to mimic human feeding behaviour and diets containing three dose rates of saxitoxin dihydrochloride (STX.2HCl) were fed to mice for 21 days. This yielded STX.2 $\mathrm{HCl}$ dose rates of up to $730 \mu \mathrm{g} / \mathrm{kg} \mathrm{bw} /$ day with no effects on food consumption, growth, blood pressure, heart rate, motor coordination, grip strength, blood chemistry, haematology, organ weights or tissue histology. Using the 100-fold safety factor to extrapolate from animals to humans yields a dose rate of $7.3 \mu \mathrm{g} / \mathrm{kg}$ bw/day, which is well above the current acute reference dose (ARfD) of $0.5 \mu \mathrm{g}$ STX.2 $\mathrm{HCl} \mathrm{eq} / \mathrm{kg}$ bw proposed by the European Food Safety Authority. Furthermore, to reach the dose rate of $7.3 \mu \mathrm{g} / \mathrm{kg}$ bw, a 60 or $70 \mathrm{~kg}$ human would have to consume 540 or $630 \mathrm{~g}$ of shellfish contaminated with PSTs at the current regulatory limit $(800 \mu \mathrm{g} / \mathrm{kg}$ shellfish flesh), respectively. The current regulatory limit for PSTs therefore seems appropriate.
\end{abstract}

Keywords: saxitoxin; feeding study; toxicology; paralytic shellfish toxins

Key Contribution: The feeding of saxitoxin dihydrochloride to mice for 21 days using a protocol to mimic human feeding behaviour showed no adverse effects at a dose rate of up to $730 \mu \mathrm{g}$ $\mathrm{STX} .2 \mathrm{HCl} / \mathrm{kg}$ bw/day. These results suggest that the current regulatory limit for PSPs is protective of human health.

\section{Introduction}

Paralytic shellfish poisoning (PSP) is induced by the ingestion of shellfish contaminated with paralytic shellfish toxins (PSTs). These toxins are produced by the marine dinoflagellates of the genera Alexandruim, Gymnodinium and Pyrodinium [1-3], and are accumulated by filter-feeding shellfish. The major PST is saxitoxin (STX), although over fifty structurally related analogues make up this toxin class [4]. PSP is characterised by tingling and numbness around the lips, incoordination and muscle weakness, as well as neurological symptoms such as headaches [5]. In severe cases, muscular paralysis will be marked and respiratory paralysis can result in death. This intoxication is not location specific and throughout history PSP outbreaks have been regularly reported worldwide [6,7]. 
The first such report was documented in a ship captain's diary in 1793 when five crew members became ill after eating mussels harvested off the coast of British Columbia which resulted in one death [8]. In Alaska, the first case of PSP was in 1799, and between 1973 and 1994, there were 54 outbreaks resulting in 117 people falling ill. Of those affected, one person died, four required intubation and 29 required emergency treatment [9]. In order to protect human health, a regulatory limit for PSTs has been adopted by many countries. Currently the regulatory limit for the European Union (EU) is set at $800 \mu \mathrm{g} \mathrm{STX.2HCl}$ eq $/ \mathrm{kg}$ shellfish flesh (regulation (EC) No 853/2004) [10]. The same limit was adopted at the twenty-eighth session of the Codex Committee on Fish and Fishery Products (CCFFP) in 2006 [11], resulting in the development of the Standard for Live and Raw Bivalve Molluscs (CODEXSTAN 292-2008, rev. 2015) [12]. This standard is used in many countries, including New Zealand. Because STX hydrate (the free base) is of low stability, the STX limit is expressed as saxitoxin dihydrochloride (STX.2HCl). It is of vital importance that whenever PST mass concentrations are mentioned, it is specified whether this refers to the salt (STX.2HCl) or to the free base (STX hydrate). This information is needed to interpret results and to allow the comparison of concentrations quoted in different studies [13]. The regulatory limit is also expressed in terms of STX equivalents (STX.2 $\mathrm{HCl}$ eq) as the PSTs include more than just STX, and other derivatives may simultaneously be present in the shellfish ingested by humans. To accommodate this, the toxicity data of each analogue is compared to that of STX on a molar basis to yield a toxicity equivalence factor (TEF). Using the TEF values, the concentrations of each analogue, as determined by analytical methods, can be converted into STX.2HCl equivalents such that the overall toxicity of a given sample can be evaluated against the regulatory limit.

Estimating the quantity of PSTs that have been responsible for reported cases of human illness is very difficult as a number of different pieces of information are required including an accurate determination of the amount of toxin in the food (STX.2HCl eq), the quantity of contaminated shellfish eaten, and the bodyweight of the person. The quantity of shellfish eaten is often not known and it is rare for the weight of the patient to be reported in the literature. Furthermore, there is often a time lag between the consumption of contaminated shellfish and the diagnosis of PSP, meaning that remnant food is rarely available for analysis. While shellfish can be harvested from the affected area, this is not necessarily representative of the food ingested and it has been demonstrated that the concentrations of PSP toxins can change very quickly in shellfish [14]. In addition, the effects of different cooking processes on PST concentrations are uncertain and whether broth or cooking liquid is consumed or discarded adds another layer of complexity $[15,16]$.

By considering the available data on human PSP cases, the European Food Safety Authority (EFSA) determined that the quantity of STX which could be consumed in a $24 \mathrm{~h}$ period without adverse effect, the acute reference dose (ARfD), was $0.5 \mu \mathrm{g} \mathrm{STX.2HCl} \mathrm{eq/} \mathrm{kg}$ bw [7]. To relate this to the quantities which could be ingested by consumers of shellfish, three pieces of information are required: the STX concentration in the shellfish, the quantity of shellfish consumed (portion size), and the bodyweight of the consumer. In calculations of risk, the concentration of STX in shellfish is assumed to be at the current NZ/Codex/EU regulatory limit ( $800 \mu \mathrm{g}$ STX.2HCl eq/ $\mathrm{kg}$ shellfish flesh). Understandably, portion size will vary greatly throughout the population, making it difficult to select an appropriate value. A large portion size of $400 \mathrm{~g}$ has been proposed by EFSA which represents the 95th percentile of shellfish consumption in Germany and the Netherlands [17]. However, this value appears high as the 97.5th percentile for the portion size of shellfish eaten by adults is $133 \mathrm{~g}$ in Japan, $181 \mathrm{~g}$ in Australia, $225 \mathrm{~g}$ in the USA and $263 \mathrm{~g}$ in New Zealand, and a portion size of $250 \mathrm{~g}$ would cover $97.5 \%$ of the consumers of most countries for which data are available [8]. Although the bodyweight of adults is also highly variable, it is imperative that risk assessments are done using conservative estimates, thus ensuring that the majority of the population is covered. EFSA has used an adult bodyweight of $60 \mathrm{~kg}$ [7], but a further EFSA committee has argued that a standard bodyweight of $70 \mathrm{~kg}$ would be more appropriate [18]. Looking at the range of possible portion sizes of shellfish in particular, 
but also bodyweights, illustrates that the estimate of STX which could be ingested by a human varies widely. Using the worst-case scenario of shellfish at the regulatory limit $(800 \mu \mathrm{g}$ STX.2 $\mathrm{HCl} \mathrm{eq} / \mathrm{kg}$ shellfish flesh), a portion size of $400 \mathrm{~g}$ and a $60 \mathrm{~kg}$ adult, the dose rate consumed would be $5.3 \mu \mathrm{g}$ STX.2HCl eq $/ \mathrm{kg}$ bw. However, consumption of shellfish at the regulatory limit with a portion size of $250 \mathrm{~g}$ by a $70 \mathrm{~kg}$ adult would yield a dose rate of $2.9 \mu \mathrm{g} \mathrm{STX} .2 \mathrm{HCl} \mathrm{eq} / \mathrm{kg} \mathrm{bw}$. Although significantly different, both of these figures are above the ARfD of $0.5 \mu \mathrm{g}$ STX.2HCl eq $/ \mathrm{kg}$ bw. This difference was acknowledged by EFSA who concluded "there is a concern for the health for the consumer at the present regulatory limit" [7].

Given the uncertainties, generating regulatory limits using human cases of poisoning is difficult and as an alternative animal models can be used. Oral toxicity is the most relevant route of administration and, when available, these data are used in preference to toxicity determined by intraperitoneal injection (i.p.) [19]. To extrapolate from animal data to human, uncertainty factors are applied to animal toxicity data. Those generally applied are a ten-fold safety factor to allow for the species difference, and a further ten-fold safety factor to allow for possible susceptibility variations within a human population [20]. An acute no observable adverse effect level (NOAEL) for STX of $473 \mu \mathrm{g}$ STX.2HCl eq $/ \mathrm{kg}$ bw has been determined in mice using oral administration [21]. When the combined safety factors of 100 are applied to this figure, the concentration which would be expected to induce no adverse effects in humans is $4.7 \mu \mathrm{g}$ STX.2 $\mathrm{HCl} \mathrm{eq} / \mathrm{kg} \mathrm{bw}$. This dose rate is much higher than the ARfD suggested by EFSA $(0.5 \mu \mathrm{g}$ STX.2HCl eq $/ \mathrm{kg} \mathrm{bw})$. Comparing the Health Based Guidance Value (HBGV) to the current STX.2HCl regulatory limit of $800 \mu \mathrm{g}$ $\mathrm{STX} .2 \mathrm{HCl} \mathrm{eq} / \mathrm{kg}$ shellfish flesh is difficult because this is dependent on an estimate of portion size and human bodyweight.

While there is still debate around the validity of the current regulatory limit for PSTs, of further concern is the fact that people who eat shellfish often do so on a regular basis, and for some communities, shellfish constitutes a high proportion of their diet. Since algal blooms can be present for several months, shellfish may be contaminated with PSTs for an extended time [22-24]. Despite this, as noted by the FAO/IOC/WHO (2004) Committee, no repeated oral toxicity studies have been performed to assess whether STX has a cumulative effect or whether more subtle indications of toxicity may arise with regular sub-lethal doses [8]. To fill this significant knowledge gap, a sub-acute study with daily dosing of $\mathrm{STX} .2 \mathrm{HCl}$ to mice was performed. Feeding protocols using meal times were developed in order to more closely represent average human feeding behaviour.

\section{Results}

\subsection{Development of Experimental Protocols}

\subsubsection{Development of Suitable Diet}

Previous mouse feeding studies have been conducted by incorporating the test ingredient, such as ground endophyte-infected ryegrass seed [25] or the endophyte-expressed metabolite chanoclavine [26] with ground mouse food. In these studies, the diet portions weighed approximately $7 \mathrm{~g}$ and the compounds were found to be homogenous in the diet. However, using the same protocol, STX was found to be unevenly distributed in the diet with the STX.2 $\mathrm{HCl}$ concentration $24-40 \%$ higher at the edges of the diet portion in comparison to the middle. This difference is likely due to the high water solubility of STX which allows it to be redistributed in the diet during drying, a process which would not be possible for the seed or highly lipophilic compound used in the other studies. Modifications to the protocol where smaller portions of diet (approximately $1 \mathrm{~g}$ each) were prepared using a lower drying temperature for a shorter time rectified this issue and STX.2HCl was confirmed to be homogenously distributed in this diet.

The stability of STX.2 $\mathrm{HCl}$ in laced diet was assessed by storing individual portions $(1 \mathrm{~g})$ for a number of days in the fridge $\left(4^{\circ} \mathrm{C}\right)$ or at room temperature $\left(20^{\circ} \mathrm{C}\right)$. This showed that STX was stable in the diet for up to five days at both temperatures (Table 1). Since 
fresh diet was prepared every 2-4 days during the feeding study, the stability of STX in the mouse diet was judged to be adequate.

Table 1. Saxitoxin concentrations in mouse diet stored at different temperatures and for different time periods.

\begin{tabular}{|c|c|c|}
\hline Sample & 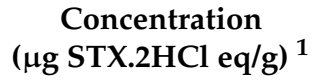 & Recovery $^{2}$ \\
\hline Day 1 Control & $3.30 \pm 0.24$ & $95 \%$ \\
\hline Day $220^{\circ} \mathrm{C}$ & $3.30 \pm 0.48$ & $95 \%$ \\
\hline Day $24{ }^{\circ} \mathrm{C}$ & $3.26 \pm 0.36$ & $94 \%$ \\
\hline Day $520^{\circ} \mathrm{C}$ & $3.33 \pm 0.24$ & $96 \%$ \\
\hline Day $54^{\circ} \mathrm{C}$ & $3.26 \pm 0.45$ & $94 \%$ \\
\hline
\end{tabular}

\subsubsection{Establishment of a Suitable STX Dose Rate}

Many studies on shellfish toxins using mice have successfully utilised a method of oral administration whereby the test toxin is mixed with a very small amount of cream cheese $[27,28]$. After training with unlaced cream cheese for a few days prior, mice will consume this laced cream cheese within $30 \mathrm{~s}$. Using this method, an acute oral dose rate of $400 \mu \mathrm{g} \mathrm{STX.2HCl} / \mathrm{kg}$ bw induced mild toxic effects in one out of three mice, so it was anticipated that this could be an appropriate dose rate for the high STX treatment group in the feeding study. However, it was found that mice with unlimited access to STX-laced diet, delivering a daily dose of $476 \mu \mathrm{g}$ STX.2HCl/ $\mathrm{kg}$ bw for two weeks, showed no adverse effects. Furthermore, mice with unlimited access to STX-laced diet to deliver a daily dose

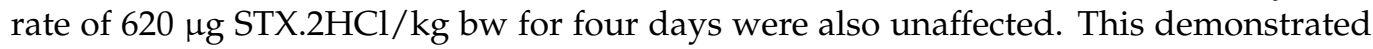
that the toxicity of STX could be influenced by the feeding protocols used in the study, highlighting the importance of using a feeding protocol that is relevant to humans. In contrast to the human feeding behaviour of meal times, the feeding behaviour of mice is that of continuous grazing. To develop a relevant feeding protocol, pairs of individually caged mice were offered either unrestricted access to control diet (no STX) or access to the same food between only 9-11 a.m. and 3-5 p.m., with food consumption being measured in both groups. This showed that for two days, mice with limited feeding times had a low daily food intake (0.029 and $0.176 \mathrm{~g}$ food/g bw on days 1 and 2, respectively) compared to those with unlimited access to food $(0.314$ and $0.296 \mathrm{~g}$ food $/ \mathrm{g}$ bw on days 1 and 2, respectively). However, by day 3 , the two groups had an equivalent total food consumption ( 0.256 compared to $0.240 \mathrm{~g}$ food $/ \mathrm{g}$ bw, for unlimited and limited, respectively). For mice fed between 9-11 a.m. and 3-5 p.m., it was observed that, at the most, they ate for only half of their $2 \mathrm{~h}$ feeding period before going to sleep. Meal times of a $1 \mathrm{~h}$ duration were therefore chosen for the feeding study.

Since no toxicity was observed on feeding STX.2HCl in laced diet, the possible effect of the matrix was investigated. A mouse with unrestricted access to control diet dosed with STX.2HCl in cream cheese to deliver a $400 \mu \mathrm{g}$ STX.2HCl $/ \mathrm{kg}$ bw dose showed a hunched posture and splayed back legs $2 \mathrm{~h}$ post-dosing, symptoms characteristic of STX toxicity. Using the meal time feeding protocol, a further two mice were taken, with one fed a STX.2HCl-laced diet and the other fed a control diet, but half way through each feeding period STX.2HCl laced cream cheese was offered, and consumed by the mouse within $30 \mathrm{~s}$. Each of these latter two mice ingested $400 \mu \mathrm{g}$ STX.2HCl/ $\mathrm{kg}$ bw at each feeding period $(800 \mu \mathrm{g} / \mathrm{kg}$ bw daily total) and neither showed any adverse effects. This demonstrates that the lack of STX.2 HCl toxicity is the same whether fed via mouse food diet laced with STX or in laced cream cheese, eliminating the possibility of a matrix effect. 


\subsection{Results of the 21-Day Feeding Study}

\subsubsection{Diet Analysis}

Preliminary work and palatability studies allowed the STX.2 $\mathrm{HCl}$ concentrations for the feeding study to be chosen. Laced diet from each treatment group was analysed to ensure that the STX.2 $\mathrm{HCl}$ concentrations were as expected. A comparison between the theoretical and actual concentrations of STX.2HCl in each of the three treatment groups showed this to be the case (Table 2).

Table 2. Saxitoxin concentrations in mouse diet for the three different treatments.

\begin{tabular}{lccc}
\hline Treatment & $\begin{array}{c}\text { Measured } \\
\text { Concentration } \\
(\mu \mathrm{g} \mathrm{STX.2HCl} \mathrm{eq/g)}\end{array}$ & $\begin{array}{c}\text { Theoretical } \\
\text { Concentration } \\
(\mu \mathrm{g} \mathrm{STX.2HCl} \mathrm{eq/g)}\end{array}$ & Recovery $^{2}$ \\
\hline Low STX & $1.12 \pm 0.20$ & 1.15 & $97 \%$ \\
Mid STX & $2.34 \pm 0.41$ & 2.27 & $103 \%$ \\
High STX & $3.19 \pm 0.56$ & 3.41 & $94 \%$ \\
\hline
\end{tabular}

${ }^{1} \pm 95 \%$ confidence interval, ${ }^{2}$ Compared to theoretical.

\subsubsection{Dose Rates}

By combining the daily food intake and bodyweight data for each individual animal, the dose rate of STX.2 $\mathrm{HCl}$ consumed each day could be calculated, thereby allowing the mean daily dose rate of STX.2HCl to be determined for each treatment group. The dose rates showed good consistency throughout the 21-day feeding period with means ( \pm standard error) of $253 \pm 5$ and $248 \pm 5 \mu \mathrm{g} / \mathrm{kg} \mathrm{bw} /$ day for female and male mice fed with low-dose STX-laced diet, $494 \pm 9$ and $486 \pm 8 \mu \mathrm{g} / \mathrm{kg}$ bw $/$ day for female and male mice fed mid-dose STX-laced diet, and $730 \pm 13$ and $699 \pm 11 \mu \mathrm{g} / \mathrm{kg}$ bw/day for female and male mice fed high-dose STX-laced diet.

\subsubsection{Clinical Observations and Appearance}

The appearance, movement and behaviour of all mice remained normal throughout the 21-day experimental period.

\subsubsection{Bodyweight and Food Consumption}

Statistical analysis of the daily food intake data showed that there was no evidence of an interaction between gender and treatment (gender.treatment.day, $p=0.940$; gender.treatment, $p=0.198$ ). A graph could therefore be created for the temporal treatment effect pooled over gender (Figure 1).

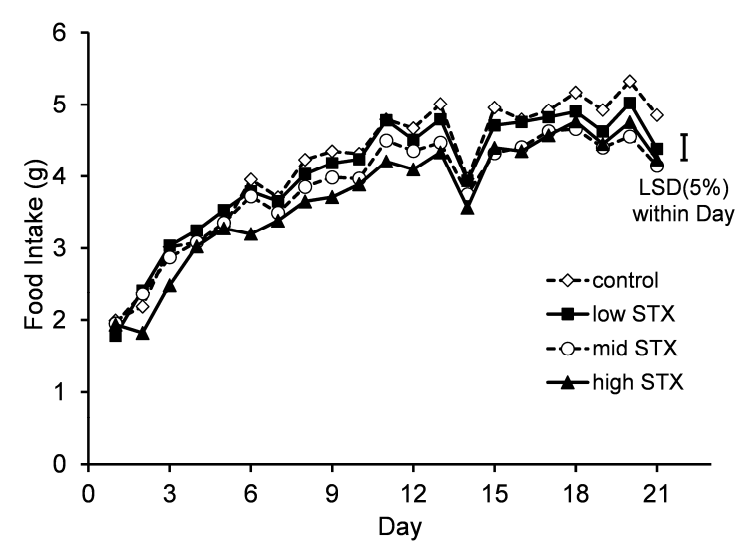

Figure 1. Temporal trend in food intake of mice fed control $\left(\cdot \vee^{*}\right)$, low STX $(-\mathbf{\square}-)$, mid STX $(\cdot \bigcirc \cdot)$ or high STX (- $\mathbf{\Delta}$-) diets $(1.14,2.28$ and $3.48 \mu \mathrm{g}$ STX.2HCl/g, respectively) over the 21-day feeding study. The error bar denotes the Fisher's unprotected least significant differences at the 5\% level (LSD (5\%)). 
The food consumption of all mice was low at the start of the study as they adapted to the meal time feeding protocol. The dips in food intake on days 14 and 21 were observed in all treatment groups and coincided with the days that motor coordination, blood pressure, heart rate and grip strength were measured. Although still present, this observed dip in food intake was less marked on day 7 when only motor coordination and grip strength were measured. This demonstrated that the measurement of blood pressure and heart rate was the major driver of this disruption of mouse feeding. The statistical analysis of the pooled data showed that although feeding of mice in all treatment groups was good, the presence of STX did cause a dose-dependent statistical effect on food intake. Mice fed a high STX diet ate a statistically lower amount of food than mice fed a control diet on 16 of the 21 days. Similarly, mice fed with a mid and low STX diet ate a statistically lower amount of food than mice fed a control diet on 9 and 1 of the 21 days, respectively.

Statistical analysis of the bodyweights of mice showed no evidence of an interaction between gender and treatment (gender.treatment.day, $p=0.918$; gender.treatment, $p=0.393$ ). A graph could therefore be created for the temporal treatment effect pooled over gender (Figure 2).

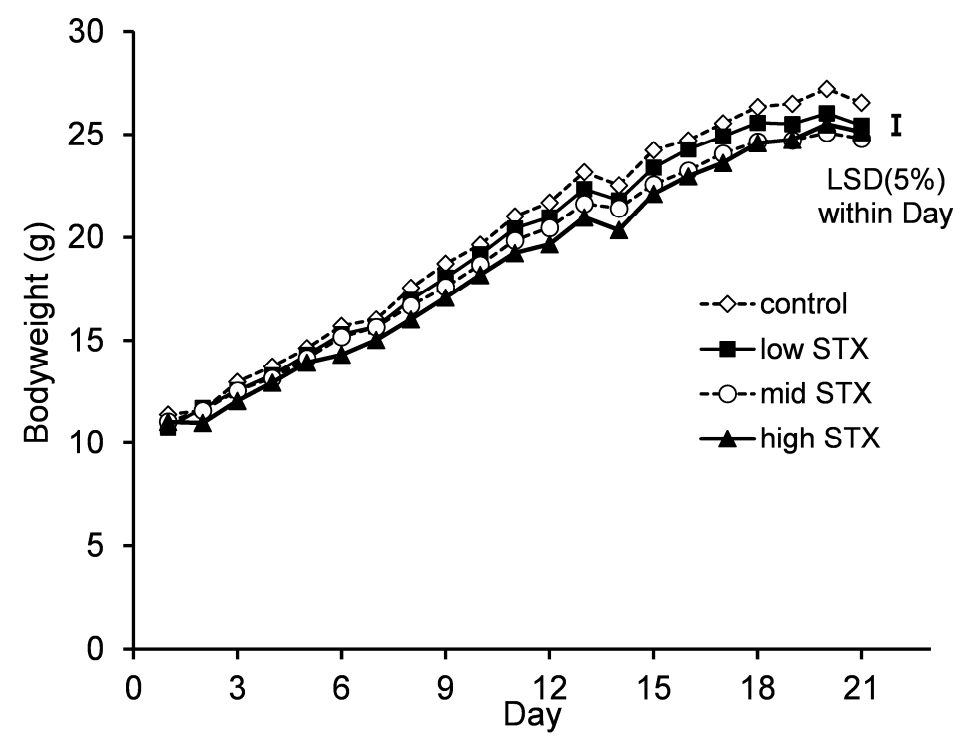

Figure 2. Temporal trend in bodyweights of mice fed control $\left(\cdot \vee^{\prime}\right)$, low STX $(-\mathbf{-}-)$, mid STX $\left(\cdot \bigcirc^{\prime}\right)$ or high STX (- $\mathbf{\Delta}$-) diets $(1.14,2.28$ and $3.48 \mu \mathrm{g}$ STX.2HCl/g, respectively) over the 21-day feeding study. The error bar denotes the Fisher's unprotected least significant differences at the 5\% level (LSD (5\%)).

This bodyweight data showed that all mice gained weight over the experimental period but mice fed a high, mid and low STX diet gained a lower amount of weight on average than mice fed a control diet on 17, 13 and 3 of the 21 days of the study, respectively.

\subsubsection{Motor Coordination}

Motor coordination of all mice was analysed on days 7, 14 and 21 using an accelerating rotarod. Statistical analysis of the motor coordination data showed no evidence of an interaction between gender and treatment (gender.treatment.day, $p=0.113$; gender.treatment, $p=0.761$ ). A graph could therefore be created for the temporal treatment effect pooled over gender (Figure 3). There were no statistically significant treatment effects on the motor coordination of mice. 


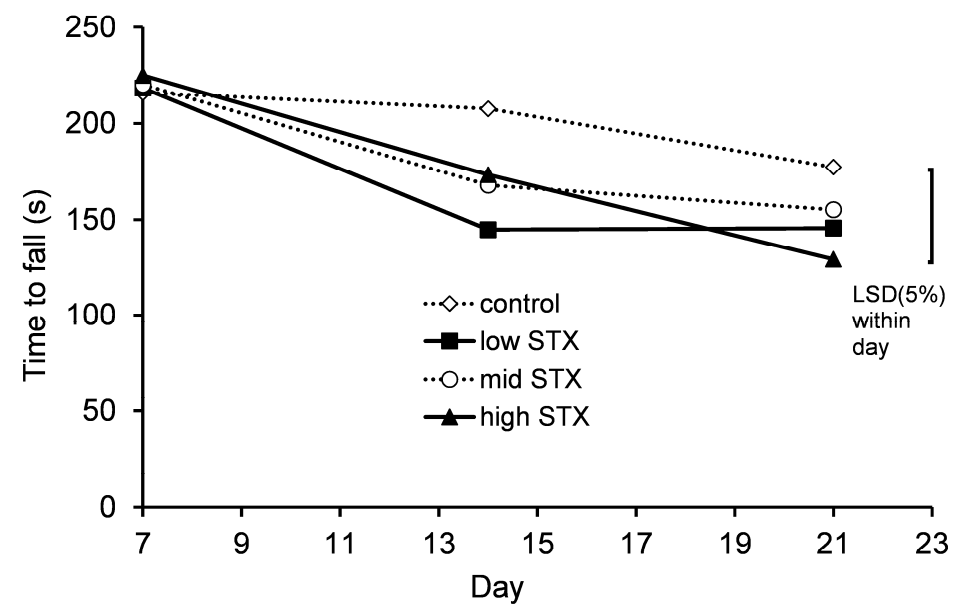

Figure 3. Temporal trend in motor coordination (time to fall) of mice fed control $(\cdot \diamond \cdot \cdot)$, low STX

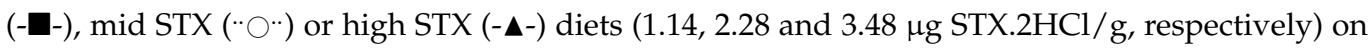
days 7 and 14 of the feeding study. The error bar denotes the Fisher's unprotected least significant differences at the $5 \%$ level (LSD (5\%)).

\subsubsection{Grip Strength}

The grip strength of all mice was analysed on days 7,14 and 21 . Statistical analysis of the grip strength data showed no evidence of an interaction between gender and treatment (gender.treatment.day, $p=0.574$; gender.treatment, $p=0.334$ ). A graph could therefore be created for the temporal treatment effect pooled over gender (Figure 4). The data showed no statistically significant treatment effects on the grip strength of mice.

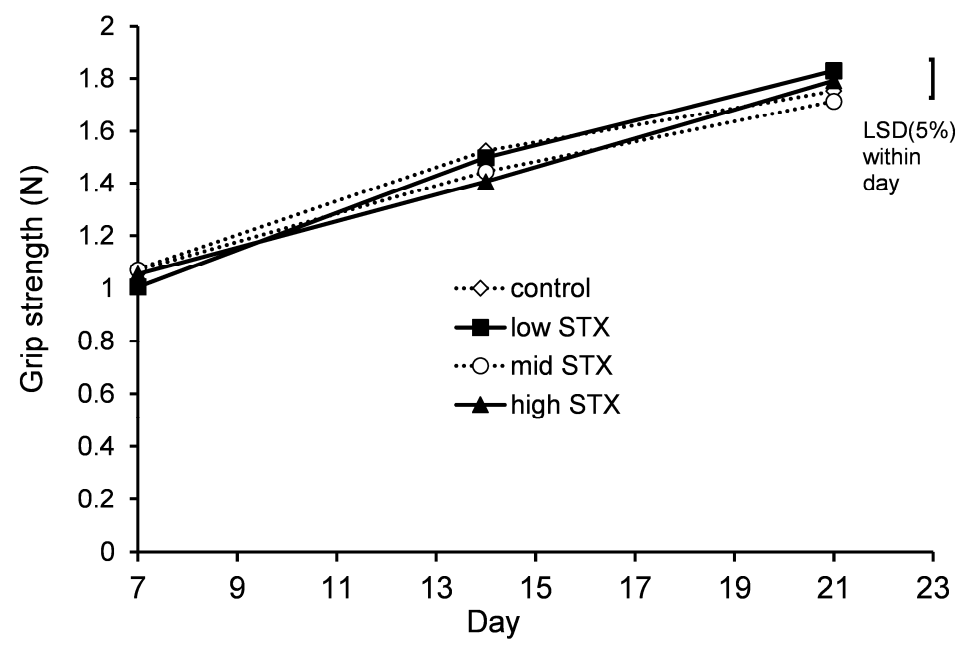

Figure 4. Temporal trend in grip strength of mice fed control $\left(\cdot \diamond^{\prime} \cdot\right)$, low STX $(-\mathbf{\square}-)$, mid STX ("○*) or high STX (-ム-) diets $(1.14,2.28$ and $3.48 \mu \mathrm{g}$ STX.2HCl/g, respectively) on days 7,14 and 21 of the feeding study. The error bar denotes the Fisher's unprotected least significant differences at the 5\% level (LSD (5\%)).

\subsubsection{Blood Pressure and Heart Rate}

The blood pressure and heart rate were measured in all mice on days 14 and 21 (Table 3). Measurements were not possible prior to day 14 as the mice were too small to fit into the blood pressure analysis system. There were no statistically significant differences observed in systolic blood pressure, diastolic blood pressure or heart rate between any of the treatment groups. 
Table 3. Heart rate and blood pressure of mice fed control, low STX, mid STX or high STX diets $(1.14,2.28$ and $3.48 \mu \mathrm{g}$ STX. $2 \mathrm{HCl} / \mathrm{g}$, respectively) on days 14 and 21 of the feeding study.

\begin{tabular}{|c|c|c|c|c|c|c|}
\hline & \multicolumn{2}{|c|}{$\begin{array}{l}\text { Heart Rate } \\
\text { (BPM) }\end{array}$} & \multicolumn{2}{|c|}{$\begin{array}{c}\text { Systolic BP } 1 \\
\text { (mmHg) }\end{array}$} & \multicolumn{2}{|c|}{$\begin{array}{c}\text { Diastolic BP } 1 \\
(\mathrm{mmHg})\end{array}$} \\
\hline & Day 14 & Day 21 & Day 14 & Day 21 & Day 14 & Day 21 \\
\hline $\begin{array}{l}\text { Females } \\
\text { control }\end{array}$ & $729 \pm 16.7^{a}$ & $710 \pm 16.7^{a}$ & $112.6 \pm 6.89^{a}$ & $119.0 \pm 6.89^{a}$ & $45.8 \pm 4.20^{\mathrm{a}}$ & $52.0 \pm 4.20^{a}$ \\
\hline low & $732 \pm 16.7^{a}$ & $679 \pm 16.7^{a}$ & $110.2 \pm 6.89^{a}$ & $118.4 \pm 6.89^{a}$ & $54.4 \pm 4.20^{\mathrm{a}}$ & $57.2 \pm 4.20^{a}$ \\
\hline mid & $753 \pm 16.7^{a}$ & $690 \pm 16.7^{a}$ & $105.4 \pm 6.89^{a}$ & $111.0 \pm 6.89^{a}$ & $52.6 \pm 4.20^{\mathrm{a}}$ & $49.4 \pm 4.20^{a}$ \\
\hline high & $754 \pm 16.7^{\mathrm{a}}$ & $699 \pm 16.7^{a}$ & $99.4 \pm 6.89^{\mathrm{a}}$ & $106.0 \pm 6.89^{a}$ & $43.6 \pm 4.20^{\mathrm{a}}$ & $52.8 \pm 4.20^{a}$ \\
\hline $\begin{array}{l}\text { Males } \\
\text { control }\end{array}$ & 709. $\pm 16.7^{\mathrm{a}}$ & $704 \pm 16.7^{a}$ & $108.4 \pm 6.89^{\mathrm{a}}$ & $111.8 \pm 6.89^{a}$ & $48.2 \pm 4.20^{\mathrm{a}}$ & $48.0 \pm 4.20^{a}$ \\
\hline low & $701 . \pm 16.7^{a}$ & $692 \pm 16.7^{a}$ & $105.2 \pm 6.89^{\mathrm{a}}$ & $119.4 \pm 6.89^{a}$ & $41.0 \pm 4.20^{\mathrm{a}}$ & $49.2 \pm 4.20^{a}$ \\
\hline mid & $753 \pm 16.7^{\mathrm{a}}$ & $695 \pm 16.7^{a}$ & $101.4 \pm 6.89^{a}$ & $116.2 \pm 6.89^{a}$ & $42.8 \pm 4.20^{\mathrm{a}}$ & $50.8 \pm 4.20^{a}$ \\
\hline high & $729 \pm 16.7^{a}$ & $680 \pm 16.7^{a}$ & $112.6 \pm 6.89^{a}$ & $116.0 \pm 6.89^{a}$ & $50.8 \pm 4.20^{\mathrm{a}}$ & $50.8 \pm 4.20^{a}$ \\
\hline
\end{tabular}

${ }^{1}$ Values are means \pm standard error of the mean $(n=5)$. Fisher's unprotected least significant differences were used to compare the treatment means within each sex. Two means that have no letter in common are statistically different at the $5 \%$ level.

\subsubsection{Haematological and Serum Biochemical Data}

The haematological data of blood samples collected on day 21 are presented in Table 4. For the haemoglobin level (HB), a small, but dose-dependent, decrease was seen for the male mice with the means of the mid STX and high STX treatment groups being statistically significantly different from that of the control group. However, this treatment group effect was less compelling for the female mice, with no statistically significant differences between the control group and any of the three STX treatment groups, making it unlikely that the differences seen in the male mice were of any significance. The mean white blood cell counts were highest in the control group for both genders, although it was only the values for male mice which showed a statistically significant difference. Furthermore, there was no STX dose-dependent effect for either gender, meaning that these results are unlikely to be toxicologically significant.

Table 4. Haematology data of mice fed control, low STX, mid STX or high STX diets $(1.14,2.28$ and $3.48 \mu \mathrm{g}$ STX.2HCl/g, respectively) for 21 days.

\begin{tabular}{|c|c|c|c|c|}
\hline Item & Control $^{1}$ & Low STX ${ }^{1}$ & $\operatorname{Mid}_{\text {STX }}{ }^{1}$ & High STX ${ }^{1}$ \\
\hline \multicolumn{5}{|l|}{ Females } \\
\hline $\mathrm{HCT}(\mathrm{L} / \mathrm{L})$ & $0.45 \pm 0.01^{\mathrm{a}}$ & $0.47 \pm 0.01^{\mathrm{a}}$ & $0.46 \pm 0.01^{\mathrm{a}}$ & $0.44 \pm 0.01^{\mathrm{a}}$ \\
\hline $\mathrm{HB}(\mathrm{g} / \mathrm{L})$ & $136 \pm 2.9^{a b}$ & $141 \pm 2.9^{b}$ & $138 \pm 2.9^{a b}$ & $132 \pm 2.9^{\mathrm{a}}$ \\
\hline $\operatorname{RBC}\left(\times 10^{12} / \mathrm{L}\right)$ & $8.29 \pm 0.21^{a}$ & $8.75 \pm 0.21^{a}$ & $8.61 \pm 0.21^{a}$ & $8.31 \pm 0.21^{\mathrm{a}}$ \\
\hline $\mathrm{MCV}(\mathrm{fL})$ & $54.5 \pm 0.70^{\mathrm{a}}$ & $53.9 \pm 0.70^{a}$ & $53.9 \pm 0.70^{a}$ & $53.3 \pm 0.70^{\mathrm{a}}$ \\
\hline $\mathrm{MCH}(\mathrm{pg})$ & $16.4 \pm 0.18^{a}$ & $16.2 \pm 0.18^{a}$ & $16.0 \pm 0.18^{a}$ & $16.0 \pm 0.18^{a}$ \\
\hline $\mathrm{MCHC}(\mathrm{g} / \mathrm{L})$ & $303 \pm 3.1^{\mathrm{a}}$ & $299 \pm 3.1^{\mathrm{a}}$ & $297 \pm 3.1^{\mathrm{a}}$ & $299 \pm 3.1^{\mathrm{a}}$ \\
\hline $\mathrm{WBC}\left(\times 10^{9} / \mathrm{L}\right)$ & $6.51 \pm 0.82^{a}$ & $5.51 \pm 0.82^{a}$ & $4.55 \pm 0.82^{\mathrm{a}}$ & $5.25 \pm 0.82^{\mathrm{a}}$ \\
\hline Neutrophil (\%) & $9.56 \pm 2.73^{a}$ & $11.24 \pm 2.73^{a}$ & $6.76 \pm 2.73^{a}$ & $10.56 \pm 2.73^{a}$ \\
\hline Lymphocyte (\%) & $87.3 \pm 3.84^{\mathrm{a}}$ & $85.3 \pm 3.84^{a}$ & $91.9 \pm 3.84^{\mathrm{a}}$ & $85.7 \pm 3.84^{\mathrm{a}}$ \\
\hline Monocyte (\%) & $1.29 \pm 0.95^{\mathrm{a}}$ & $2.71 \pm 0.95^{\mathrm{a}}$ & $0.89 \pm 0.95^{\mathrm{a}}$ & $1.89 \pm 0.95^{\mathrm{a}}$ \\
\hline Eosinophil (\%) & $0.89 \pm 0.586^{\mathrm{a}}$ & $0.91 \pm 0.586^{\mathrm{a}}$ & $0.29 \pm 0.586^{\mathrm{a}}$ & $1.29 \pm 0.586^{\mathrm{a}}$ \\
\hline \multicolumn{5}{|l|}{ Males } \\
\hline $\mathrm{HCT}(\mathrm{L} / \mathrm{L})$ & $0.46 \pm 0.01^{\mathrm{a}}$ & $0.47 \pm 0.01^{\mathrm{a}}$ & $0.46 \pm 0.01^{\mathrm{a}}$ & $0.45 \pm 0.01^{\mathrm{a}}$ \\
\hline $\mathrm{HB}(\mathrm{g} / \mathrm{L})$ & $137 \pm 2.9^{b}$ & $136 \pm 2.9^{b}$ & $135 \pm 2.9^{a b}$ & $128 \pm 2.9^{a}$ \\
\hline $\operatorname{RBC}\left(\times 10^{12} / \mathrm{L}\right)$ & $8.58 \pm 0.21^{\mathrm{a}}$ & $8.57 \pm 0.21^{\mathrm{a}}$ & $8.57 \pm 0.21^{a}$ & $8.12 \pm 0.21^{\mathrm{a}}$ \\
\hline $\mathrm{MCV}(\mathrm{fL})$ & $54.0 \pm 0.70^{a}$ & $54.7 \pm 0.70^{\mathrm{a}}$ & $53.5 \pm 0.70^{a}$ & $54.8 \pm 0.70^{\mathrm{a}}$ \\
\hline $\mathrm{MCH}(\mathrm{pg})$ & $16.0 \pm 0.18^{\mathrm{a}}$ & $16.0 \pm 0.18^{\mathrm{a}}$ & $16.0 \pm 0.18^{\mathrm{a}}$ & $16.0 \pm 0.18^{\mathrm{a}}$ \\
\hline $\mathrm{MCHC}(\mathrm{g} / \mathrm{L})$ & $295 \pm 3.1^{\mathrm{a}}$ & $291 \pm 3.1^{\mathrm{a}}$ & $294 \pm 3.1^{\mathrm{a}}$ & $288 \pm 3.1^{\mathrm{a}}$ \\
\hline $\mathrm{WBC}\left(\times 10^{9} / \mathrm{L}\right)$ & $7.36 \pm 0.82^{b}$ & $4.51 \pm 0.82^{\mathrm{a}}$ & $5.25 \pm 0.82^{\mathrm{a}}$ & $5.62 \pm 0.82^{\mathrm{ab}}$ \\
\hline
\end{tabular}


Table 4. Cont.

\begin{tabular}{lllll}
\hline Item & Control $^{\mathbf{1}}$ & Low STX $^{\mathbf{1}}$ & Mid STX $^{\mathbf{1}}$ & High STX $^{\mathbf{1}}$ \\
\hline Neutrophil (\%) & $13.85 \pm 2.73^{\mathrm{b}}$ & $13.44 \pm 2.73^{\mathrm{b}}$ & $11.64 \pm 2.73^{\mathrm{ab}}$ & $5.95 \pm 2.73^{\mathrm{a}}$ \\
Lymphocyte (\%) & $82.4 \pm 3.84^{\mathrm{a}}$ & $84.5 \pm 3.84^{\mathrm{a}}$ & $85.3 \pm 3.84^{\mathrm{a}}$ & $90.9 \pm 3.84^{\mathrm{a}}$ \\
Monocyte (\%) & $2.40 \pm 0.95^{\mathrm{a}}$ & $1.31 \pm 0.95^{\mathrm{a}}$ & $1.71 \pm 0.95^{\mathrm{a}}$ & $2.41 \pm 0.95^{\mathrm{a}}$ \\
Eosinophil (\%) & $1.00 \pm 0.586^{\mathrm{a}}$ & $0.91 \pm 0.586^{\mathrm{a}}$ & $1.51 \pm 0.586^{\mathrm{a}}$ & $0.78 \pm 0.586^{\mathrm{a}}$ \\
\hline
\end{tabular}

${ }^{1}$ Values are means \pm standard error of the mean $(n=5)$. Fisher's unprotected least significant differences were used to compare the treatment means within each sex. Two means that have no letter in common are statistically different at the 5\% level. HCT, haematocrit value; HB, haemoglobin level; RBC, red blood cells; $\mathrm{MCV}$, mean corpuscular volume; $\mathrm{MCH}$, mean corpuscular haemoglobin; $\mathrm{MCHC}$, mean corpuscular haemoglobin concentration; WBC, white blood cells.

The serum biochemical data of blood samples collected on day 21 are presented in Table 5. The aspartate aminotransferase (AST) and alanine aminotransferase (ALT) data were log transformed to stabilise the variance. For female mice, the log ALT is statistically significantly higher for the control than for any of the STX fed mice, but this effect did not show a dose-dependent trend. Furthermore, male mice fed a control diet had the lowest $\log$ ALT of any of the treatment groups meaning that this observation is highly unlikely to be of toxicological significance. Creatinine was also statistically significantly higher in the control female group in comparison to the treatment groups fed low STX and mid STX diets. However, no difference was seen between the female control and STX high dose mice, and no effect was seen in the male mice, pointing to random chance rather than any effect of treatment. For the male mice, the log AST was statistically higher in the STX high dose group in comparison to the control, but since the trend in the female mice was the opposite, this is unlikely to be of any importance.

Table 5. Serum biochemical data of mice fed control, low STX, mid STX or high STX diets (1.14, 2.28 and $3.48 \mu \mathrm{g}$ STX.2HCl/g, respectively) for 21 days.

\begin{tabular}{|c|c|c|c|c|}
\hline Item & Control $^{1}$ & Low STX ${ }^{1}$ & $\operatorname{Mid}$ STX $^{1}$ & High STX ${ }^{1}$ \\
\hline \multicolumn{5}{|l|}{ Females } \\
\hline $\log$ AST $(\log I U / L)$ & $5.81 \pm 0.33^{a}$ & $5.27 \pm 0.33^{a}$ & $5.45 \pm 0.33^{\mathrm{a}}$ & $5.46 \pm 0.33^{\mathrm{a}}$ \\
\hline $\log$ ALT $(\log$ IU/L) & $5.25 \pm 0.35^{b}$ & $3.65 \pm 0.35^{\mathrm{a}}$ & $4.01 \pm 0.35^{\mathrm{a}}$ & $3.85 \pm 0.35^{\mathrm{a}}$ \\
\hline Urea $(\mathrm{mmol} / \mathrm{L})$ & $8.96 \pm 2.12^{a}$ & $9.50 \pm 2.12^{\mathrm{a}}$ & $8.94 \pm 2.12^{\mathrm{a}}$ & $7.72 \pm 2.12^{\mathrm{a}}$ \\
\hline $\mathrm{TP}(\mathrm{g} / \mathrm{L})$ & $47.0 \pm 1.7^{\mathrm{a}}$ & $47.33 \pm 1.7^{\mathrm{a}}$ & $49.07 \pm 1.7^{\mathrm{a}}$ & $51.25 \pm 1.7^{\mathrm{a}}$ \\
\hline $\operatorname{ALB}(\mathrm{g} / \mathrm{L})$ & $28.6 \pm 1.03^{a}$ & $28.0 \pm 1.03^{a}$ & $29.0 \pm 1.03^{a}$ & $30.6 \pm 1.03^{\mathrm{a}}$ \\
\hline Globulin (g/L) & $19.8 \pm 0.87^{a}$ & $19.5 \pm 0.87^{\mathrm{a}}$ & $20.5 \pm 0.87^{\mathrm{a}}$ & $21.3 \pm 0.87^{\mathrm{a}}$ \\
\hline CRN $(\mu \mathrm{mol} / \mathrm{L})$ & $10.4 \pm 1.04^{b}$ & $7.8 \pm 1.04^{\mathrm{a}}$ & $7.2 \pm 1.04^{\mathrm{a}}$ & $9.4 \pm 1.04^{\mathrm{ab}}$ \\
\hline $\mathrm{A} / \mathrm{G}$ ratio & $1.39 \pm 0.03^{\mathrm{a}}$ & $1.41 \pm 0.03^{\mathrm{a}}$ & $1.42 \pm 0.03^{\mathrm{a}}$ & $1.44 \pm 0.03^{\mathrm{a}}$ \\
\hline $\mathrm{Na}(\mathrm{mmol} / \mathrm{L})$ & $151 \pm 1.3^{\mathrm{a}}$ & $152 \pm 1.3^{\mathrm{a}}$ & $152 \pm 1.3^{\mathrm{a}}$ & $149 \pm 1.3^{\mathrm{a}}$ \\
\hline $\mathrm{K}(\mathrm{mmol} / \mathrm{L})$ & $8.07 \pm 0.71^{\mathrm{a}}$ & $7.81 \pm 0.71^{\mathrm{a}}$ & $7.53 \pm 0.71^{\mathrm{a}}$ & $8.35 \pm 0.71^{\mathrm{a}}$ \\
\hline $\mathrm{Cl}(\mathrm{mmol} / \mathrm{L})$ & $114.0 \pm 1.02^{\mathrm{a}}$ & $113.4 \pm 1.02^{\mathrm{a}}$ & $114.6 \pm 1.02^{\mathrm{a}}$ & $113.2 \pm 1.02^{\mathrm{a}}$ \\
\hline \multicolumn{5}{|l|}{ Males } \\
\hline $\log$ AST $(\log I U / L)$ & $4.72 \pm 0.33^{\mathrm{a}}$ & $5.27 \pm 0.33^{a b}$ & $5.05 \pm 0.33^{a b}$ & $5.75 \pm 0.33^{b}$ \\
\hline $\log$ ALT $(\log$ IU/L) & $3.54 \pm 0.35^{\mathrm{a}}$ & $3.58 \pm 0.35^{\mathrm{a}}$ & $3.68 \pm 0.35^{\mathrm{a}}$ & $3.79 \pm 0.35^{\mathrm{a}}$ \\
\hline Urea $(\mathrm{mmol} / \mathrm{L})$ & $9.08 \pm 2.12^{\mathrm{a}}$ & $10.00 \pm 2.12^{\mathrm{a}}$ & $9.86 \pm 2.12^{\mathrm{a}}$ & $9.65 \pm 2.12^{\mathrm{a}}$ \\
\hline $\mathrm{TP}(\mathrm{g} / \mathrm{L})$ & $50.7 \pm 1.7^{\mathrm{a}}$ & $50.7 \pm 1.7^{\mathrm{a}}$ & $51.0 \pm 1.7^{\mathrm{a}}$ & $49.7 \pm 1.7^{\mathrm{a}}$ \\
\hline $\operatorname{ALB}(\mathrm{g} / \mathrm{L})$ & $28.2 \pm 1.03^{\mathrm{a}}$ & $28.6 \pm 1.03^{\mathrm{a}}$ & $28.8 \pm 1.03^{\mathrm{a}}$ & $28.2 \pm 1.03^{\mathrm{a}}$ \\
\hline Globulin (g/L) & $22.5 \pm 0.87^{\mathrm{a}}$ & $22.7 \pm 0.87^{\mathrm{a}}$ & $22.3 \pm 0.87^{\mathrm{a}}$ & $21.7 \pm 0.87^{\mathrm{a}}$ \\
\hline CRN $(\mu \mathrm{mol} / \mathrm{L})$ & $7.0 \pm 1.04^{\mathrm{a}}$ & $5.9 \pm 1.04^{\mathrm{a}}$ & $6.1 \pm 1.04^{\mathrm{a}}$ & $7.1 \pm 1.04^{\mathrm{a}}$ \\
\hline $\mathrm{A} / \mathrm{G}$ ratio & $1.24 \pm 0.03^{\mathrm{a}}$ & $1.26 \pm 0.03^{a}$ & $1.28 \pm 0.03^{\mathrm{a}}$ & $1.30 \pm 0.03^{\mathrm{a}}$ \\
\hline $\mathrm{Na}(\mathrm{mmol} / \mathrm{L})$ & $152 \pm 1.3^{\mathrm{a}}$ & $151 \pm 1.3^{\mathrm{a}}$ & $151 \pm 1.3^{\mathrm{a}}$ & $152 \pm 1.3^{\mathrm{a}}$ \\
\hline $\mathrm{K}(\mathrm{mmol} / \mathrm{L})$ & $8.17 \pm 0.71^{\mathrm{a}}$ & $8.53 \pm 0.71^{\mathrm{a}}$ & $9.43 \pm 0.71^{\mathrm{a}}$ & $8.93 \pm 0.71^{\mathrm{a}}$ \\
\hline $\mathrm{Cl}(\mathrm{mmol} / \mathrm{L})$ & $111.4 \pm 1.02^{\mathrm{a}}$ & $113.0 \pm 1.02^{\mathrm{a}}$ & $112.0 \pm 1.02^{\mathrm{a}}$ & $114.0 \pm 1.02^{\mathrm{a}}$ \\
\hline
\end{tabular}

${ }^{1}$ Values are mean \pm standard error of the mean $(n=5)$. Fisher's unprotected least significant differences were used to compare the treatment means within each sex. Two means that have no letter in common are statistically different at the 5\% level. AST, aspartate aminotransferase; ALT, alanine aminotransferase; TP, total protein; ALB, albumin; CRN, creatinine. 


\subsubsection{Organ Weights}

The organ weights of all mice, expressed as the percentage of bodyweight, are presented in Table 6. There was no strong statistical evidence of an overall treatment effect on relative organ weights. Neither the interaction between gender and treatment $(p \geq 0.065)$ or the main effect of treatment ( $p \geq 0.081$ ) was statistically significant at the $5 \%$ level for any of the organs expressed as percentage of bodyweight. When the pairwise comparisons within gender were examined (Table 6), some statistically significant differences between the means were observed. However, in each case, there was either no dose-dependency or the effect was only seen in one gender. It is therefore unlikely that any of these observations are of any toxicological significance.

Table 6. Organ weights, expressed as percentage of bodyweight, for mice fed control, low STX, mid STX or high STX diets $(1.14,2.28$ and $3.48 \mu \mathrm{g}$ STX.2HCl/g, respectively) for 21 days.

\begin{tabular}{lllll}
\hline Item & Control $^{\mathbf{1}}$ & Low STX $^{\mathbf{1}}$ & Mid STX $^{\mathbf{1}}$ & High STX $^{\mathbf{1}}$ \\
\hline Females & & & & \\
brain & $1.86 \pm 0.09^{\mathrm{ab}}$ & $1.83 \pm 0.09^{\mathrm{a}}$ & $1.96 \pm 0.09^{\mathrm{ab}}$ & $2.01 \pm 0.09^{\mathrm{b}}$ \\
heart & $0.58 \pm 0.03^{\mathrm{a}}$ & $0.55 \pm 0.03^{\mathrm{a}}$ & $0.60 \pm 0.03^{\mathrm{a}}$ & $0.57 \pm 0.03^{\mathrm{a}}$ \\
kidneys & $1.34 \pm 0.07^{\mathrm{a}}$ & $1.24 \pm 0.07^{\mathrm{a}}$ & $1.30 \pm 0.07^{\mathrm{a}}$ & $1.30 \pm 0.07^{\mathrm{a}}$ \\
liver & $4.59 \pm 0.10^{\mathrm{a}}$ & $4.32 \pm 0.10^{\mathrm{a}}$ & $4.41 \pm 0.10^{\mathrm{a}}$ & $4.38 \pm 0.10^{\mathrm{a}}$ \\
spleen & $0.39 \pm 0.03^{\mathrm{a}}$ & $0.42 \pm 0.03^{\mathrm{a}}$ & $0.37 \pm 0.03^{\mathrm{a}}$ & $0.38 \pm 0.03^{\mathrm{a}}$ \\
\hline Males & & & & \\
brain & $1.73 \pm 0.09^{\mathrm{a}}$ & $1.72 \pm 0.09^{\mathrm{a}}$ & $1.74 \pm 0.09^{\mathrm{a}}$ & $1.83 \pm 0.09^{\mathrm{a}}$ \\
heart & $0.57 \pm 0.03^{\mathrm{a}}$ & $0.63 \pm 0.03^{\mathrm{b}}$ & $0.57 \pm 0.03^{\mathrm{ab}}$ & $0.55 \pm 0.03^{\mathrm{a}}$ \\
kidneys & $1.72 \pm 0.07^{\mathrm{b}}$ & $1.74 \pm 0.07^{\mathrm{b}}$ & $1.66 \pm 0.07^{\mathrm{ab}}$ & $1.59 \pm 0.07^{\mathrm{a}}$ \\
liver & $4.74 \pm 0.10^{\mathrm{a}}$ & $4.65 \pm 0.10^{\mathrm{a}}$ & $4.69 \pm 0.10^{\mathrm{a}}$ & $4.54 \pm 0.10^{\mathrm{a}}$ \\
spleen & $0.37 \pm 0.03^{\mathrm{b}}$ & $0.32 \pm 0.03^{\mathrm{ab}}$ & $0.34 \pm 0.03^{\mathrm{ab}}$ & $0.29 \pm 0.03^{\mathrm{a}}$ \\
\hline
\end{tabular}

${ }^{1}$ Values are mean \pm standard error of the mean $(n=5)$. Fisher's unprotected least significant differences were used to compare the treatment means within each sex. Two means that have no letter in common are statistically different at the $5 \%$ level.

\subsubsection{Histological Examination}

No significant changes in tissues were visible on histological examination in mice from any of the treatment groups.

\section{Discussion}

In this experiment, using a meal time feeding protocol, male and female mice were fed daily dose rates of up to 699 and $730 \mu \mathrm{g}$ STX.2HCl $/ \mathrm{kg}$ bw / day, respectively, for 21 days, without developing any signs of toxicity (average of $715 \mu \mathrm{g} \mathrm{STX.2HCl} / \mathrm{kg}$ bw/day). A small, but dose-dependent, effect of STX on the food intake of mice was detected. This may have been due to palatability of the diet to mice or it may have been due to postdigestional malaise. This will be explored further in a future experiment. None of the mice showed any behavioural or physiological effects, the serum biochemistry was normal, and in addition, there were no changes detected at histopathological examination of tissue samples. The NOAEL of STX.2HCl, administered using a meal time feeding protocol, is therefore greater than $715 \mu \mathrm{g}$ STX.2HCl $/ \mathrm{kg}$ bw. Taking into account the 100 -fold safety factor to extrapolate from animal data to humans, this yields a human safe level equivalent of $7.2 \mu \mathrm{g} \mathrm{STX.2HCl} / \mathrm{kg}$. The dose rates used in this study far exceed the ARfD of $0.5 \mu \mathrm{g}$ STX.2HCl $/ \mathrm{kg}$ bw suggested by EFSA. To reach the human equivalent of the dose rates used in this study $(7.2 \mu \mathrm{g}$ STX.2HCl $/ \mathrm{kg} \mathrm{bw})$, a $60 \mathrm{~kg}$ human would have to ingest $540 \mathrm{~g}$ of shellfish flesh contaminated with PSTs at the current regulatory limit $(800 \mu \mathrm{g}$ STX.2HCl $/ \mathrm{kg}$ flesh). For a human weighing a more realistic $70 \mathrm{~kg}$, this portion size increases to $630 \mathrm{~g}$. The highest shellfish portion size proposed for use in risk assessment is that of $400 \mathrm{~g}$ by EFSA [7]. However, the FAO/IOC/WHO (2004) Committee noted that a portion size of 250 $\mathrm{g}$ would cover $97.5 \%$ of the consumers of most countries for which data were available [8]. 
Animal models, using the oral route of exposure, will reflect the potential human health risk of toxins in food. In this experiment, feeding was chosen as the method of oral administration rather than gavage. This was for a number of reasons. Tingling and numbness of the lips and mouth have been reported as amongst the first symptoms of human PSP cases which demonstrates that local absorption of the toxins through the buccal mucous membranes occurs with oral ingestion of these toxins [29]; this process would be bypassed by using gavage administration. Additionally, numerous studies have shown that gavage dosing overestimates the toxicity of shellfish toxins [21,30]. This is likely due to the consistency of mouse stomach contents as, unlike humans, the stomach contents of rodents are semi-solid which could allow part of the liquid gavage dose to flow around them to be rapidly absorbed by the duodenum [19,31]. In contrast, if the test compound is incorporated with a solid matrix, it mixes with the existing stomach contents. Furthermore, a study by Craig and Elliott [32] using radiolabelled protein showed that $38 \%$ of mice dosed by gavage $(27 / 71)$ did not receive their liquid dose correctly. Mice which had received an incorrect gavage dose showed no changes in behaviour meaning that they could not be distinguished from those which had been successfully dosed. This was attributed to occasional spillover/regurgitation of the dosing material into the lungs and led the authors to conclude that "the common method of gavage feeding mice to assess absorption of orally ingested material can lead to artifacts not seen when the same agent is consumed under more natural circumstances" [32].

As an alternative to gavage, we incorporated STX.2HCl into the diet of mice. Although laced cream cheese has been used successfully in acute toxicity testing [27], this was not suitable for a feeding study as, over time, mice tend to start refusing to eat the dose, an effect which would have a major impact on the study. As an alternative, STX was incorporated into the normal diet of mice, a method which worked well. Mice with unlimited access to STX-containing diet ingested a dose rate of up to $620 \mu \mathrm{g} \mathrm{STX.2HCl} / \mathrm{kg}$ bw $/$ day for four days without any symptoms of toxicity. Given that the oral $\mathrm{LD}_{50}$ for $\mathrm{STX} .2 \mathrm{HCl}$ in mice is $1063 \mu \mathrm{g} / \mathrm{kg}$ bw and the NOAEL is $473 \mu \mathrm{g} / \mathrm{kg}$ bw [21], this lack of toxicity was surprising. However, a one-off bolus dose, such as that used in the acute toxicity work, is a vastly different scenario to the constant exposure to small quantities of STX over a long period of time as would occur with the unrestricted feeding protocol. The feeding behaviour of mice is one of many bouts of feeding (grazing), with $70 \%$ of food consumed in the dark and 30\% during the light [33,34]. This pattern is totally different to human feeding behaviour which is that of meal times and which would result in the ingestion of STX over a much shorter time period. To replicate this scenario, a feeding protocol was developed whereby mice were fed for two $1 \mathrm{~h}$ feeding periods per day. Mice quickly adapted to this change in feeding regime and after a training period of three days their daily food intake was normal. Preliminary testing of STX.2HCl using this protocol also showed a surprising lack of toxicity. It has been suggested by other authors [35] that the ingestion of PSTs mixed with $150 \mathrm{mg}$ of cream cheese may influence toxicity due to the high fat content of cream cheese. To ensure that the lack of observed toxicity with feeding was not simply a matrix effect (cream cheese versus mouse food), one mouse was fed meals of diet laced with STX, while another was fed meals of control diet along with STX-laced cream cheese. Both methods delivered the same high dose rate of STX.2HCl $(400 \mu \mathrm{g} / \mathrm{kg}$ bw twice a day) and both showed no symptoms of toxicity. In contrast, a mouse with unrestricted access to control diet developed severe symptoms of toxicity after just one bolus dose of $400 \mu \mathrm{g} \mathrm{STX.2HCl} / \mathrm{kg}$ bw in cream cheese. This difference in toxicity must therefore be caused by the different quantity of food in the stomach of mice at the time of STX ingestion. With unlimited access to food, the stomach of a mouse would be relatively empty in the morning when the STX-laced cream cheese was consumed as a bolus dose. In contrast, the mice fed meals of STX-laced diet consumed half of their daily food intake along with the STX, resulting in the stomach containing considerable solid material. The quantity of matrix (food) in the stomach of mice is therefore impacting the absorption of STX and thus influencing toxicity. Relating this to a human scenario, STX in pure form 
cannot be eaten, meaning that it is not possible to ingest STX on an empty stomach. Even the standard portion size of $100 \mathrm{~g}$ determined by EFSA would result in the ingestion of a significant amount of matrix (food) along with the STX. In this experiment, using the meal time feeding protocol, mice were fed daily dose rates of up to $730 \mu \mathrm{g}$ STX. $2 \mathrm{HCl} / \mathrm{kg}$ bw/day for 21 days without developing any signs of toxicity.

The high dose rate used in our feeding study, which induced no adverse effects, is at odds with a study by Arnich and Thébault [36] who, on the basis of the quantitative modelling of human PSP cases, proposed a lowest observed adverse effect level (LOAEL) of $0.37 \mu \mathrm{g}$ STX.2HCl eq $/ \mathrm{kg}$ bw. After applying the 100 -fold safety factor for extrapolation from animals to human, the NOAEL determined in our feeding study was almost 20 times lower than this figure. However, as discussed earlier, the STX.2HCl concentrations in leftover food, the quantity of shellfish eaten and the bodyweight of the human are required to effectively interpret PSP cases. The Arnich and Thébault [36] model was based on 13 outbreaks of PSP which were often missing some of these crucial pieces of information. Furthermore, in all but one of the outbreaks, the PSP toxin analysis was conducted by mouse bioassay (MBA) [37]. This MBA was developed in the 1930s, whereby the relationship between the i.p. dose of pure STX.2HCl and the death time of mice was established to yield a dose-death time curve [38]. This curve was then used to convert the death time of mice injected with shellfish samples into STX.2HCl equivalents. However, PSTs are comprised of a large number of analogues and it has been demonstrated that the different analogues can have a dose-death time curve which is not consistent with that of STX [28]. The MBA approach therefore does not accurately determine the concentrations of PSTs. With the advanced analytical tools now available, along with the push for better information to be collected from patients presenting at hospitals with PSP, better data to input into the model should be available in the future. Another study which appears to contradict our results is that of Boente-Juncal et al. [39] who administered combinations of STX and tetrodotoxin (TTX) by gavage for 28 days. The dose rates used were very low, $44 \mu \mathrm{g}$ TTX/kg bw along with $5.3,17$ or $54 \mu \mathrm{g}$ STX.2HCl/ kg bw. Surprisingly, one out of the four mice dosed at the lowest dose and two out of five mice dosed at the highest dose rate died. Each of these deaths were described as sudden convulsions and rapid death which perhaps could be attributable to the inherent issues with gavage dosing. Given the mouse deaths, symptoms of toxicity would have been expected in the surviving mice, but all survivors showed no symptoms of toxicity and gained weight normally. The mechanism of action for both STX and TTX is via voltage-gated sodium channels and the toxicities of the two toxins are additive when administered orally [21], resulting in the recommendation that TTX should be added to the PSTs. For this reason, it is valid to add the STX and TTX dose rates given in the Boente-Juncal et al. (2020) study [39] to allow a comparison with those administered in our study. The combined STX and TTX dose rates administered by gavage were 56.6, 68.3 and $105.3 \mu \mathrm{g}$ STX.2HCl eq/ $\mathrm{kg}$ bw. In comparison, the STX.2HCl dose rate administered to mice using the meal time feeding protocol in our study was $715 \mu \mathrm{g}$ STX.2HCl eq/ kg bw, seven times higher and with no adverse effects observed.

This feeding study showed no evidence of a cumulative effect of STX in mice, and on the basis of the high dose rates of STX.2HCl given using the meal time feeding protocol, designed to replicate human feeding behaviour, the current regulatory limit for PSTs seems adequate to protect human health. For the determination of this regulatory limit, the PSP cases considered by EFSA were all from the ingestion of non-commercial shellfish samples. Regulation of commercial samples has led to rigorous routine monitoring programmes and it was recognized by the working group convened to "assess the advice from the joint FAO/WHO/IOC Ad Hoc expert consultation on biotoxins and bivalve molluscs" that using the current limit of $800 \mu \mathrm{g}$ STX.2HCl eq/ kg shellfish flesh has resulted in no human illnesses from commercially harvested shellfish for 50 years [11]. This observation, as in our experiment, indicates that the current regulatory level for PSTs is fit for purpose. Since no toxicity was observed in the study, the true NOAEL exceeds the highest dose administered. To determine the true NOAEL, further work, using higher dose rates, would 
be required. This study highlighted that the feeding regime has a big influence on the toxicity of STX.2HCl. Further work is planned to better define this difference as it is possible that the current methods to determine acute oral toxicity for use in the setting of regulatory limits is overestimating the risk of these toxins to human health. It would be interesting to investigate whether the impact of feeding regime on toxicity is confined to just STX or whether it also occurs with other toxin classes.

\section{Materials and Methods}

\subsection{Purity Assessment of Saxitoxin}

STX was supplied by the Cawthron Institute (Nelson, NZ) and calibrated against certified reference material from the National Research Council of Canada (NRC) using HPLC-UV at $210 \mathrm{~nm}$ and a method adapted from Rourke et al. [40]. Ion pairing chromatography was performed on a Zorbax Bonus RP $4.6 \times 150 \mathrm{~mm} 3.5 \mu \mathrm{m}$ column under isocratic conditions over $30 \mathrm{~min}$ at $1 \mathrm{~mL} / \mathrm{min}$ with $11 \mathrm{mM}$ heptane sulfonate, $16.5 \mathrm{mM}$ phosphoric acid $11.5 \%$ acetonitrile adjusted to $\mathrm{pH} 7.1$ with ammonium hydroxide. Additionally, trace concentrations of other PSTs were quantified using LC-MS/MS [41], showing the material to contain $99.8 \%$ STX, $0.16 \%$ decarbamoylSTX and $0.05 \%$ neoSTX. The STX material was stored at $4{ }^{\circ} \mathrm{C}$ as a stock solution in $3 \mathrm{mM} \mathrm{HCl}$ at a concentration of $10.91 \mathrm{mg} / \mathrm{mL} \mathrm{STX.2HCl}$. For preparation of mouse diet, working solutions were prepared gravimetrically using $3 \mathrm{mM} \mathrm{HCl}$ as the diluting solvent.

\subsection{Animals}

Swiss albino mice were used for all experimental work. Females were used for the preliminary studies; however, for the feeding study, mice of both genders were used. Mice were individually caged in a temperature-controlled room $\left(21 \pm 1^{\circ} \mathrm{C}\right)$ with a 12 -h light-dark cycle and with unrestricted access to water. During the feeding study, a housing arrangement was used where the boxes, each containing an individual mouse, were randomised for columns and rows such that the eight combinations of treatment group and gender occurred exactly once along each row (forming the experimental replicate) and no more than once down each column.

\subsection{Preparation of Mouse Diets}

Mouse diets were based on Teklad Global 2016 mouse food pellets (Harlan UK, Bicester, UK) ground to a fine flour using a cyclone sample mill (Udy Corporation, Fort Collins, CO, USA). To check for STX homogeneity in the diet, a test batch was prepared by mixing ground mouse food $(50 \mathrm{~g})$ with water $(45 \mathrm{~mL})$ containing STX.2 $\mathrm{HCl}(13.5 \mu \mathrm{g})$. This mixture was well combined and seven cookie-shaped portions of diet (approximately $2.5 \times 2.5 \times 1 \mathrm{~cm})$ were prepared and dried in a fan oven $\left(50^{\circ} \mathrm{C}\right.$ for $\left.24 \mathrm{~h}\right)$. After the drying process had been completed, three different areas of one portion of the STX-laced diet were taken and ground using a mortar and pestle. The STX concentration was measured by the analysis of duplicate samples by LC-MS/MS. Since analysis showed that homogeneity was a problem in this diet, a further test batch of STX-laced diet was prepared by taking ground mouse food $(25 \mathrm{~g})$ and mixing this with water $(20 \mathrm{~mL})$ containing STX.2HCl $(87.5 \mu \mathrm{g})$. This mixture was well-combined and 25 small cookie-shaped portions of diet $(1.5 \mathrm{~cm}$ diameter and $0.6 \mathrm{~cm}$ thickness) were prepared and dried in a fan oven at a lower temperature and for a shorter time $\left(30^{\circ} \mathrm{C}\right.$ for $\left.16 \mathrm{~h}\right)$ compared to the initial batch. The resulting STX-laced diet was extracted and analysed (as detailed in Section 4.4), which showed that the homogeneity issue had been resolved. To check the stability of STX, portions of the laced diet were stored at both $4{ }^{\circ} \mathrm{C}$ and $20^{\circ} \mathrm{C}$. Two samples of the stored diet were taken on days 1, 2 and 5, and processed as detailed in Section 4.4. Each sample was analysed in triplicate.

During the feeding trial, $50 \mathrm{~g}$ batches of STX-laced diet were prepared as above, resulting in 50 small portions of diet. Each batch was weighed at the end of the drying process so that the moisture contents could be calculated. The average moisture content was $14.1 \%$ for the control diet, $15.4 \%$ for the low dose STX diet, $13.3 \%$ for the mid dose 
STX diet and $14.2 \%$ for the high dose STX diet. To determine the concentrations of the three different STX diets used in the feeding trial, two samples of each treatment diet were ground using a mortar and pestle and then analysed in quadruplicate using the methods described in Section 4.4. Prepared diets were kept at $4{ }^{\circ} \mathrm{C}$ until use and were prepared at least every three days during the feeding study.

\subsection{LC-MS Analysis}

To determine the STX concentration in laced diet, samples were taken $(200 \pm 5 \mathrm{mg})$ and extracted with $0.1 \mathrm{M} \mathrm{HCl}(10 \mathrm{~mL})$ by placing them in a boiling water bath (5 min). The extracts were then cooled in an ice bath (5 min), briefly mixed on a vortex mixer and then centrifuged $(17,000 \times g$ for $5 \mathrm{~min})$. An aliquot of the resulting extract $(10 \mu \mathrm{L})$ was added to $80 \%$ acetonitrile with $0.25 \%$ acetic acid $(490 \mu \mathrm{L})$ in a polypropylene autosampler vial and analysed by UHPLC-MS/MS based on the method of Turner et al. [42], using a 6500+ QTRAP tandem quadrupole mass spectrometer coupled to an Exion LC liquid chromatography separations system, with high $\mathrm{pH}$ compatibility conversion composed of a multiplate autosampler, binary solvent pumps with low pressure gradient proportioning valve solvent selection, and a column oven with 6-port 2-position column selection valve. Curtain gas was 25 psi, ion source gas 1 was 50 psi, ion source gas 2 was 50 psi, ionspray voltage was -4500 in negative mode, and $5500 \mathrm{~V}$ in positive mode, the temperature was $500{ }^{\circ} \mathrm{C}$, and declustering potential was $-30 \mathrm{~V}$ in negative mode and $30 \mathrm{~V}$ in positive mode. Scheduled MRM mode was used for data acquisition with STX monitored in positive ion mode with MRM transitions 300.141 > 204.088 (CE 34 V) and 300.141 > 138.066 (CE 36 V).

\subsection{Preliminary Work and Palatability Studies}

To determine an appropriate STX dose rate, pairs of mice were housed together and given unrestricted access to STX-laced diet. Food consumption and bodyweight were measured daily to allow the calculation of the STX dose rate ingested. Initially, a pair of mice was fed a diet containing $2.43 \mu \mathrm{g}$ STX.2HCl/g for 14 days, which delivered an average dose rate of $476 \mu \mathrm{g}$ STX.2HCl/ $\mathrm{kg}$ bw / day. In a further trial, a pair of mice was fed a diet containing $2.95 \mu \mathrm{g} \mathrm{STX.2HCl/g}$ for four days, which delivered an average dose rate of $620 \mu \mathrm{g}$ STX.2HCl/kg bw/day.

To develop experimental protocols to replicate human feeding behaviour, one individually caged mouse was given unrestricted access to control diet and another was fed the same diet between only 8-10 a.m. and 3-5 p.m. for eight days. Daily food intake and bodyweight were measured to allow $\mathrm{g}$ food consumed/g bw to be calculated.

To ensure that the administration of STX in the laced diet was not influencing toxicity, three weanling mice were taken and individually caged. Mouse 1 had unrestricted access to control diet and was trained to eat small quantities of cream cheese following a method previously described [21]. Mouse 2 was trained in the meal time feeding protocol using control diet as well as being trained to eat small quantities of cream cheese, and mouse 3 was trained in the meal time feeding protocol using control diet. After four days of training, mouse 1 continued to have unrestricted access to control diet but was fed cream cheese (150 mg) laced with STX. Mouse 2 was fed control diet at meal times along with cream cheese $(150 \mathrm{mg})$ laced with STX half-way through each of its two daily feeding periods, and mouse 3 was fed STX-laced diet at meal times. Mouse 1 ingested $400 \mu \mathrm{g}$ STX.2HCl/ $\mathrm{kg}$ bw as a one-off bolus dose, and both mouse 2 and 3 ingested $400 \mu \mathrm{g}$ STX.2HCl/ kg bw at each of their twice daily feeding periods. The mice were observed closely for any signs of toxicity throughout the day.

\subsection{Sub-Acute 21-Day Feeding Trial}

Sixty weanling mice (30 female and 30 male) were individually caged and trained in the meal time feeding protocol. To allow a more gradual adjustment to the change in feeding regime, mice were given access to food between 9 a.m. and 5 p.m. for one day, and then for the following three days were fed between 9-10 a.m. and 3.30-4.30 p.m. 
This period of training was completed with control diet. On each day of the training period, the amount of food consumed by each mouse at each meal time was measured. On each of the two days before the start of the study, mice were trained on an accelerating rotarod (Rotamex 4/8, Columbus Instruments International, Columbus, OH, USA) by placing them on the accelerating rod (13-79 rpm over $12 \mathrm{~min}$ ) and recording the time to fall. Each mouse was given two attempts per day. Mice which did not adapt to the meal time feeding protocol or those which performed poorly during training on the accelerating rotarod were excluded from the study. From those mice remaining, 20 females and 20 males were selected and randomly assigned to treatment groups. Four treatment groups, each containing five female and five male mice (individually caged) were fed between 9-10 a.m. and 3.30-4.30 p.m. for 21 days with the following diets. Group 1-control diet, Group 2-low-dose STX-laced diet $(1.14 \mu \mathrm{g} \mathrm{STX.2HCl} / \mathrm{g})$, Group 3-mid-dose STX-laced diet (2.28 $\mu \mathrm{g} \mathrm{STX.2HCl/g),} \mathrm{and} \mathrm{Group} \mathrm{4-high-dose} \mathrm{STX-laced} \mathrm{diet} \mathrm{(3.39} \mathrm{\mu g} \mathrm{STX.2HCl/g).} \mathrm{All}$ animals had unrestricted access to water and food consumption was measured after each twice daily meal time. In addition, after each daily afternoon feed, the bodyweight of each mouse was recorded and posture/appearance noted. On days 14 and 21, heart rate and blood pressure was determined for each mouse using a Visitech Systems BP-2000 blood pressure analysis system (Visitech Systems, Apex, NC, USA). On days 0, 7, 14 and 21, motor coordination was evaluated using the accelerating rotarod as described above and grip strength was measured using a grip strength meter (MK3805S, Muromachi, Tokyo, Japan). On each measurement day, the mice were given two trials on the rotarod and grip strength meter, with the results being averaged. At the end of the 21-day feeding period, mice were euthanised by $\mathrm{CO}_{2}$ inhalation and blood samples collected by heart puncture with heparin as the anticoagulant. Haematocrit values (HCT), haemoglobin levels (HB), mean corpuscular volumes (MCV), mean corpuscular haemoglobin (MCH), mean corpuscular haemoglobin concentrations (MCHC), and red and white blood cell counts were measured in whole blood. In addition, plasma was analysed for activities of aspartate aminotransferase (AST), alanine aminotransferase (ALT), and for levels of urea, total protein (TP), albumin (ALB), globulin, sodium, potassium, chloride and creatinine (CRN) (IDEXX laboratories, Hamilton, NZ). At necropsy, any macroscopic changes observed were recorded and the weights of brain, heart, kidneys, liver and spleen measured and expressed as percentages of bodyweight. These tissues, together with adrenals, lungs, pancreas, gastrocnemius, jejunum ( $3 \mathrm{~mm}$ section), ovary/uterus or testes, spinal cord $(3 \times 2 \mathrm{~mm}$ sections), stomach (washed), thymus and urinary bladder were fixed in $4 \%$ buffered formaldehyde and routinely processed for histological examination. All samples were assessed by the same pathologist who was blinded to the treatment group of the samples.

\subsection{Statistical Analysis}

The bodyweight, food consumption, motor coordination, grip strength, blood pressure and heart rate data were analysed using repeated measures formulated as linear mixed effects models and fitted using residual maximum likelihood (REML). The random model comprised of random effects for replicate (i.e., the row in the housing arrangement) and mouse. The basic fixed model comprised of effects for treatment group, day, gender and all two- and three-way interactions. In the analyses of bodyweight and food consumption date, pre-treatment (i.e., day 0) bodyweight was also included as a fixed effect covariate, and in the analyses of motor coordination and grip strength, the pre-treatment measurement on day 0 was included as a fixed effect covariate. Repeated measures on the same mouse over time were assumed to be correlated with a first-order autoregressive structure.

The haematological, serum biochemical and organ weight data were analysed using linear mixed effects models fitted using REML with random effects for replicate and fixed effects for kill day, treatment group, gender and the treatment group by gender interaction. Serum AST and ALT were log transformed to stabilise the variance.

In all analyses, the variance components were constrained to be positive, residual diagnostic plots were inspected for evidence of departures from the residual assumptions 
of normality and constant variance, a 5\% significance level was used when assessing the fixed effects, and Fisher's unprotected least significant differences at the 5\% level (LSD $(5 \%))$ were used to compare means. Statistical analyses were performed using Genstat 19th Edition (VSN International, Hemel Hempstead, UK).

Author Contributions: Conceptualization, S.C.F., D.T.H., M.J.B. and J.N.; formal analysis, V.M.C.; data curation, S.C.F., N.G.W., J.M.S., R.B.B., J.S.M. and M.J.B.; writing-original draft preparation, S.C.F., M.J.B. and V.M.C.; writing-review and editing, All authors have read and agreed to the published version of the manuscript.

Funding: This work was funded by the New Zealand Ministry for Business, Innovation and Employment-Seafood Safety research programme (Contract CAWX1801).

Institutional Review Board Statement: All animal manipulations were approved by the Ruakura Animal Ethics Committee established under the Animal Protection (code of ethical conduct) Regulations Act, 1987 (New Zealand). The project number for this study was 14673 and the approval date was 10 February 2019.

Data Availability Statement: The data presented in this study are available on request from the corresponding author.

Acknowledgments: We thank Bobby Smith and Genevieve Sheriff, AgResearch Ltd., Ruakura Science Centre, for the care of animals.

Conflicts of Interest: The authors declare no conflict of interest.

\section{References}

1. Anderson, D.M.; Alpermann, T.J.; Cembella, A.D.; Collos, Y.; Masseret, E.; Montresor, M. The globally distributed genus Alexandrium: Multifaceted roles in marine ecosystems and impacts on human health. Harmful Algae 2012, 14, 10-35. [CrossRef]

2. Oshima, Y.; Blackburn, S.I.; Hallegraeff, G.M. Comparative study on paralytic shellfish toxin profiles of the dinoflagellate Gymnodinium catenatum from three different countries. Mar. Biol. 1993, 116, 471-476. [CrossRef]

3. Usup, G.; Kulis, D.M.; Anderson, D.M. Growth and toxin production of the toxic dinoflagellate Pyrodinium bahamense var. compressum in laboratory cultures. Nat. Toxins 1994, 2, 254-262. [CrossRef]

4. Wiese, M.; D’Agostino, P.M.; Mihali, T.K.; Moffitt, M.C.; Neilan, B.A. Neurotoxic alkaloids: Saxitoxin and its analogs. Mar. Drugs 2010, 8, 2185-2211. [CrossRef]

5. García, C.; Lagos, M.; Truan, D.; Lattes, K.; Véjar, O.; Chamorro, B.; Iglesias, V.; Andrinolo, D.; Lagos, N. Human intoxication with paralytic shellfish toxins: Clinical parameters and toxin analysis in plasma and urine. Biol. Res. 2005, 38, 197-205. [CrossRef]

6. Mons, M.N.; Van Egmond, H.P.; Speijers, G.J.A. Paralytic Shellfish Poisoning: A Review; RIVM Report 388802 005; National Institute of Public Health and the Environment: Bilthoven, The Netherlands, 1988.

7. EFSA. Scientific opinion of the panel on contaminants in the food chain on a request from the european commission on marine biotoxins in shellfish-Saxitoxin group. EFSA J. 2009, 1019, 1-76.

8. FAO/IOC/WHO. Report of the Joint FAO/IOC/WHO Ad Hoc Expert Consultation on Biotoxins in Bivalve Molluscs; Food and Agriculture Organization of the United Nations: Oslo, Norway, 2004; p. 31.

9. Gessner, B.D.; Middaugh, J.P. Paralytic shellfish poisoning in Alaska: A 20-year retrospective analysis. Am. J. Epidemiol. 1995, 141, 766-770. [CrossRef]

10. European Union. Regulation (EC) No 853/2004 of the European Parliament and of the Council of 29 April 2004, Laying down specific hygiene rules for food of animal origin. Off. J. Eur. Union 2004, L 139/55, 151.

11. Yasumoto, T.; Murata, M.; Oshima, Y.; Sano, M.; Matsumoto, G.K.; Clardy, J. Diarrhetic shellfish toxins. Tetrahedron 1985, 41, 1019-1025. [CrossRef]

12. Bricelj, V.M.; Shumway, S.E. Paralytic shellfish toxins in bivalve molluscs: Occurrence, transfer kinetics, and biotransformation. Rev. Fish. Sci. 1998, 6, 315-383. [CrossRef]

13. Turnbull, A.R.; Harwood, D.T.; Boundy, M.J.; Holland, P.T.; Hallegraeff, G.; Malhi, N.; Quilliam, M.A. Paralytic shellfish toxins -Call for uniform reporting units. Toxicon 2020, 178, 59-60. [CrossRef] [PubMed]

14. Tennant, A.D.; Naubert, J.; Corbeil, H.E. An outbreak of paralytic shellfish poisoning. Can. Med. Assoc. J. 1955, 72, 436-439. [PubMed]

15. Wong, C.-K.; Hung, P.; Lee, K.L.H.; Mok, T.; Kam, K.-M. Effect of steam cooking on distribution of paralytic shellfish toxins in different tissue compartments of scallops Patinopecten yessoensis. Food Chem. 2009, 114, 72-80. [CrossRef]

16. Medcof, J.C.; Leim, A.H.; Needler, A.B.; Needler, A.W.H.; Gibbard, J.; Naubert, J. Paralytic Shellfish Poisoning on the Canadian; Atlantic coast, Bulletin No. 75; Fisheries Research Board of Canada: Ottawa, ON, USA, 1947; p. 31.

17. EFSA Marine biotoxins in shellfish—Summary on regulated marine biotoxins. EFSA J. 2009, 7, 1306. 
18. EFSA Scientific Committee. Guidance on selected default values to be used by the EFSA Scientific Committee, Scientific Panels and Units in the absence of actual measured data. EFSA J. 2012, 10, 2579.

19. FAO/WHO. Technical Paper on Toxicity Equivalency Factors for Marine Biotoxins Associated with Bivalve Molluscs; FAO: Rome, Italy, 2016; 108p.

20. Interdepartmental Group on Health Risks from Chemicals. Uncertainty Factors: Their Use in Human Health Risk Assessment by UK Government; MRC Institute for Environment and Health: Leicester, UK, 2003; p. 69.

21. Finch, S.C.; Boundy, M.J.; Harwood, D.T. The acute toxicity of tetrodotoxin and tetrodotoxin-saxitoxin mixtures to mice by various routes of administration. Toxins 2018, 10, 423. [CrossRef]

22. Harwood, D.T.; Boundy, M.; Selwood, A.I.; van Ginkel, R.; MacKenzie, L.; McNabb, P.S. Refinement and implementation of the Lawrence method (AOAC 2005.06) in a commercial laboratory: Assay performance during an Alexandrium catenella bloom event. Harmful Algae 2013, 24, 20-31. [CrossRef]

23. MacKenzie, A.L. The risk to New Zealand shellfish aquaculture from paralytic shellfish poisoning (PSP) toxins. N. Z. J. Mar. Freshw. Res. 2014, 48, 430-465. [CrossRef]

24. Turner, A.D.; Stubbs, B.; Coates, L.; Dhanji-Rapkova, M.; Hatfield, R.G.; Lewis, A.M.; Rowland-Pilgrim, S.; O’Neil, A.; Stubbs, P.; Ross, S.; et al. Variability of paralytic shellfish toxin occurrence and profiles in bivalve molluscs from Great Britain from official control monitoring as determined by pre-column oxidation liquid chromatography and implications for applying immunochemical tests. Harmful Algae 2014, 31, 87-99. [CrossRef] [PubMed]

25. Finch, S.C.; Munday, J.S.; Munday, R.; Kerby, J.W.F. Short-term toxicity studies of loline alkaloids in mice. Food Chem. Toxicol. 2016, 94, 243-249. [CrossRef]

26. Finch, S.C.; Munday, J.S.; Sprosen, J.M.; Bhattarai, S. Toxicity studies of chanoclavine in mice. Toxins 2019, 11, 249. [CrossRef]

27. Munday, R. Toxicology of Seafood Toxins: A Critical Review. In Seafood and Freshwater Toxins: Pharmacology, Physiology, and Detection, 3rd ed.; Botana, L.M., Ed.; CRC Press: Boca Raton, FL, USA, 2014; pp. 197-290.

28. Munday, R.; Thomas, K.; Gibbs, R.; Murphy, C.; Quilliam, M.A. Acute toxicities of saxitoxin, neosaxitoxin, decarbamoyl saxitoxin and gonyautoxins $1 \& 4$ and $2 \& 3$ to mice by various routes of administration. Toxicon 2013, 76, 77-83. [PubMed]

29. Kao, C.Y. Paralytic shellfish poisoning. In Algal Toxins in Seafood and Drinking Water; Falconer, I.R., Ed.; Academic Press: London, UK; San Diego, CA, USA, 1993; pp. 75-86.

30. Selwood, A.I.; Waugh, C.; Harwood, D.T.; Rhodes, L.L.; Reeve, J.; Sim, J.; Munday, R. Acute toxicities of the saxitoxin congeners gonyautoxin 5 , gonyautoxin 6 , decarbamoyl donyautoxin $2 \& 3$, decarbamoyl neosaxitoxin, C-1\&2 and C-3\&4 to mice by various routes of administration. Toxins 2017, 9, 73. [CrossRef]

31. Munday, R.; Reeve, J. Risk assessment of shellfish toxins. Toxins 2013, 5, 2109-2137. [CrossRef]

32. Craig, M.A.; Elliott, J.F. Mice fed radiolabeled protein by gavage show sporadic passage of large quantities of intact material into the blood, an artifact not associated with voluntary feeding. J. Am. Assoc. Lab. Anim. Sci. 1999, 38, 18-23.

33. Ellacott, K.L.; Morton, G.J.; Woods, S.C.; Tso, P.; Schwartz, M.W. Assessment of feeding behavior in laboratory mice. Cell Metab. 2010, 12, 10-17. [CrossRef]

34. Minematsu, S.; Hiruta, M.; Taki, M.; Fujii, Y.; Aburada, M. Automatic monitoring system for the measurement of body weight, food and water consumption and spontaneous activity of a mouse. J. Toxicol. Sci. 1991, 16, 61-73. [CrossRef]

35. Boente-Juncal, A.; Vale, C.; Cifuentes, M.; Otero, P.; Camiña, M.; Rodriguez-Vieytes, M.; Botana, L.M. Chronic in vivo effects of repeated exposure to low oral doses of tetrodotoxin: Preliminary evidence of nephrotoxicity and cardiotoxicity. Toxins 2019, 11, 96. [CrossRef]

36. Arnich, N.; Thébault, A. Dose-Response modelling of paralytic shellfish poisoning (PSP) in humans. Toxins 2018, $10,141$. [CrossRef] [PubMed]

37. Anon. AOAC Official Method 959.08. Paralytic shell-fish poisoning. Biological method. In Official Methods of Analysis of AOAC International, 18th ed.; Horwitz, W., Latimer, G.W., Eds.; AOAC International: Gaithersburg, MD, USA, 2005 ; pp. 79-82.

38. Sommer, H.; Meyer, K.F. Paralytic shell-fish poisoning. Arch. Pathol. 1937, 24, 560-598.

39. Boente-Juncal, A.; Otero, P.; Rodríguez, I.; Camiña, M.; Rodriguez-Vieytes, M.; Vale, C.; Botana, L.M. Oral chronic toxicity of the safe tetrodotoxin dose proposed by the European Food Safety Authority and its additive effect with saxitoxin. Toxins 2020, 12, 312. [CrossRef] [PubMed]

40. Rourke, W.A.; Murphy, C.J.; Pitcher, G.; van de Riet, J.M.; Burns, B.G.; Thomas, K.M.; Quilliam, M.A. Rapid postcolumn methodology for determination of paralytic shellfish toxins in shellfish tissue. J. AOAC Int. 2019, 91, 589-597. [CrossRef]

41. Boundy, M.J.; Selwood, A.I.; Harwood, D.T.; McNabb, P.S.; Turner, A.D. Development of a sensitive and selective liquid chromatography-mass spectrometry method for high throughput analysis of paralytic shellfish toxins using graphitised carbon solid phase extraction. J. Chromatogr. A 2015, 1387, 1-12. [CrossRef]

42. Turner, A.D.; Dhanji-Rapkova, M.; Fong, S.Y.T.; Hungerford, J.; McNabb, P.S.; Boundy, M.J.; Harwood, D.T. Ultrahigh-performance hydrophilic interaction liquid chromatography with tandem mass spectrometry method for the determination of paralytic shellfish toxins and tetrodotoxin in mussels, oysters, clams, cockles, and scallops: Collaborative study. J. AOAC Int. 2020, 103, 533-562. [CrossRef] 